\title{
A Review: The Influence of Participation Budgeting Toward Organization Behavior Factors
}

\section{Supriyanto Ilyas*, Tri Hadyannur Dzaky, Muhammad Zulfikar Abdurohman, Jeremy Christian and Raafi Ar Rasyid Sukma}

Widyatama University, Bandung, Indonesia

*supriyanto.ilyas@widyatama.ac.id

Article History: Received:11 January 2021; Accepted: 27 February 2021; Published online: 5 April 2021

\begin{abstract}
One of the characteristics of a budget in order to function in the planning and control process is that it contains management commitment. The requirements that must be met in order to achieve managerial commitment are active participation of managers in the budget formulation process. Participation is in the form of opportunities to submit proposals as well as opportunities to negotiate in the ratification process. This study intends to examine the effect of budget participation on various factors in organizational behavior. Based on studies according to experts and previous researchers, budget participation affects various factors related to organizational behavior, including organizational commitment, work motivation and performance.
\end{abstract}

\section{Keywords: Budget participation, organizational behavior}

\section{Introduction}

The budget preparation process is an important part of the management control process. The management control process is held so that management members (managers) always have a working spirit (motivation) to perform optimally for the organization. Organizational behavior is very important in the management control process. Thus, the budget preparation process must pay attention to behavioral aspects in the organization (Anthony, 2004).

Various phenomena that occur are that even though there are organizations that carry out budget preparation, they pay less attention to matters related to the organizational aspects of the organization. Sometimes the budget set is only a target from the leader to his subordinates without any mutual agreement. This condition has the potential to cause low motivation and organizational commitment for managers who carry out budgets.

These symptoms indicate that miscommunication between superiors and subordinates still has the potential to occur frequently. Communication of superiors and subordinates is inseparable from leadership problems in an organization. Therefore, the budgeting process needs to be supported by professional and quality leadership and a conducive organizational culture. In other words, quality leadership and a good organizational culture can be used as the basis for developing the budgeting system in the organization.

The development of a budgeting system must pay attention to good budgeting principles. The most important rule in a budgeting system is the creation of a budget that contains management commitment. Management commitment is the spirit of the budget. This means that management commitment will only be realized properly if it is supported by a quality leadership process and a conducive organizational culture. Therefore, studies regarding the development of a budgeting system based on a quality leadership process and organizational culture are indispensable.

As quoted by Budi Hartono (2016), empirical research on budgeting participation in managerial performance is research that has been around since 1952 (Argyris, 1952). However, Budi Hartono argues that until now the topic of this research is still considered attractive to both Indonesian and foreign researchers.

Furthermore, Budi Hartono mentioned various studies that show that compilation participation has a positive effect on managerial performance. These research studies include: Indarto and Ayu (2011), Lina and Stella (2013), Soleha et al. (2013), Lina (2015), Moheri and Arifah (2015). However, Budi Hartono also shows various studies with the opposite results, namely the research of Syahputra (2014), Venkatesh and Blaskovich (2012) which show that participation in the budgeting process has no effect on managerial performance.

In addition, Budi Hartono mentions research that shows that participation in budgeting has an influence on managerial performance through the role of organizational commitment as a mediating variable, namely 
research conducted by Eker (2009), Dianawati (2009), Noor and Othman (2012), Syahputra (2014), Setyarini and Susty (2014).

The objectives of this study are:

1. Mapping potential problems in budgeting related to organizational behavior factors

2. Formulating an action plan in overcoming the barriers to the relationship between superiors and subordinates related to the problem of managers' participation in the budgeting process and its relation to organizational behavior factors.

3. Conducting empirical studies in the application of leadership processes, organizational culture and the development of an effective budgeting system in private universities.

From this study, it is hoped that theoretical findings can be obtained regarding the development of a budgeting system and the process of relations between superiors and subordinates in forming participation in budgeting and forming positive organizational factors in an institution. These findings are also expected to be able to enrich the study of budgeting in particular and systems. management control which is the parent of the budgeting system.

Furthermore, the results of this study are expected to be able to make a positive contribution to the development and improvement of the budgeting system in the banking industry to make it more effective. The results of this study are also expected to provide valuable input for the leadership of the Banking Industry regarding the quality of leadership, organizational culture and their influence on the development of the budgeting system.

\section{Literature Review}

\subsection{Definition of budget}

The budget is a very effective tool in the short-term planning and control process. In order to function as a planning and control tool, the budget must fulfill certain characteristics. These characteristics are (Anthony, 2006):

1. The budget is stated in units of money. However, the amount of money can be supported by units other than units of money such as units sold or units of goods produced.

2. In general, the budget covers a period of one year.

3. The budget contains one element of management commitment. In this case, the manager agrees to accept responsibility for achieving budgeted goals.

4. Budget proposals are reviewed and approved by a higher "authority" than the compiler.

5. Once approved, the budget can only be changed under certain conditions.

6. Periodically, the actual financial implementation is compared with the budget, and the deviations that occur are analyzed and the reasons explained.

As explained earlier, a key characteristic of budgets is the presence of an element of commitment between top management and budget compilers. Through this commitment, each party agrees to be mutually tied to the budget in working to achieve the goals and objectives of the organization.

The budget consists of various types or types, in general, budgets can be classified closer to the types of responsibility centers, namely: budget costs, revenue budgets, profit budgets. According to the cost center classification, the cost budget can be divided into engineering cost budgets and policy cost budgets.

\subsection{Aspects of organizational behavior in the budget}

The budget is an important part of a management control system. A control system that will greatly influence human behavior in the organization. A good Management Control System influences human behavior in the organization in the process of achieving both organizational goals and their individual goals as a member of the organization and the goals of the organization as a whole.

Budget is a plan that will be implemented by people who involved in achieving organizational goals. Therefore, the preparation of the budget must be done in such a way that the executors are motivated to carry out the budget as well as possible. Budgeting should not only cover technical aspects, but also need to consider the parties involved. Budget executives are not senseless machines, but individuals who have needs, motives 
and aspirations. This fact shows that budgeting which is part of the management accounting system will not be effective in supporting management functions without paying attention to the implementers.

Several matters relating to aspects of organizational behavior related to budgeting will be discussed here. The discussion will involve matters relating to the budget as a means of performance appraisal, the level of difficulty of the budget, as well as the participation of leaders and subordinates in budget preparation.

\subsection{Budget as a performance appraisal tool}

The budget will affect the behavior of the implementers if the budget is linked to the performance of the executor concerned. The use of the budget in relation to performance appraisal can be carried out in two patterns. First, the budget is seen as a target that must be achieved, and secondly, the budget is not used alone to measure achievement.

The budget as a target will motivate or hinder the achievement of the target depending on the level of difficulty of the budget. In the case that the budget is not alone in its use for performance appraisal, the budget is no longer seen as the only target that must be achieved, but only as one of several measuring tools. With this pattern, the budget will tend to be a motivator because budget achievement (without detrimental to long-term goals) will be seen as a good achievement even though performance appraisal is not solely based on the budget.

\subsection{Budget difficulty level}

The level of difficulty in achieving the budget will affect the motivation of budget executors. A budget that stimulates the executive's motivation is a "challenging" budget, that is, a budget that is quite difficult to achieve but the implementers believe that they are capable of implementing it.

A budget that is impossible to implement will diminish the work motivation of the implementers. Conversely, a budget that is too easy to implement will also lead to dysfunctional behavior. When the budget is too easy, implementers tend to work not at the maximum capacity level. This was done in order to avoid too large a number of profitable deviations so that in the coming year there would be no more difficult assignments due to the earlier profitable deviations.

The level of difficulty of the budget must be relatively the same among budget executors. A budget executive manager will view the budget as something unnatural if the difficulty level of the budget which is his responsibility is greater than that of his peers. This will clearly affect the manager's motivation.

\subsection{Participation of superiors and subordinates}

In order for the budget to be a motivator in achieving goals, the active participation of leaders (superiors) and executing managers (subordinates) is needed. With this active participation, budget decisions will truly be a commitment of superiors and subordinates.

Leadership participation lies in the budget review and approval process. Endorsement by the leadership should not be just a "stamp". Without the leadership's active participation in this matter, the implementers will tend to propose an easy budget so that their performance looks good. Thus, executors can expect benefits from this "achievement". In addition, the leadership still needs to follow up on the results of the budget. Without the feedback (feedback) from the leadership, the current budgeting system will not be effective.

The participation of the executive managers (as subordinates) is generally in the form of participation in budget proposals. Managers have the opportunity to plan for their respective fields of work. In addition to encouraging commitment from superiors to subordinates, this participation will also provide confidence to subordinates on the fairness of the budget. As a result, the implementers tend to be motivated to achieve the set goals.

\subsection{Participation in arranging orchids}

Participation in budgeting is the level of involvement of managers in the budget preparation process. This participation in the preparation is a feature of budget formulation that emphasizes the participation of the accountability center manager in the process of preparing and determining budget targets for which they are responsible. (Triharja, 2014). 
Miftahul Jannah and Sri Rahayu (2015) explain budgeting participation as a process that shows the involvement of individuals in an organization in budgeting and has an influence on budget targets. Furthermore, they explained that budgeting participation is an approach that can generally improve performance which in turn can increase organizational effectiveness (quoted from Nor, 2007).

Participation in Budget preparation is manifested in providing opportunities for proposals and decisionmaking through negotiations on budget targets. This involvement will make managers feel more productive because there is a feeling of achievement which will increase the commitment they have (Yenti, 2003). Budi Hartono (2014) cites Dianawati's (2009) statement that participation involving lower-level managers in budgeting can create a feeling of responsibility to meet the targets or targets that have been set in the budget.

Agus Karyadi and Sunarto (2014) state that participatory budgets provide many benefits for organizations. Previous research has shown that the higher the participation in budgeting will improve managerial performance.

Budi Hartono (2016) also cites the view of Blocher et al. (2016) which states that there is no single factor that affects the success of the budget. However, managers' support for the budget is the most important factor in the success of the budget preparation process. Through this participation, managers will feel that they have a predetermined budget so that they will be motivated in the implementation process.

Muhammad Hasby Habibie and Mahmudi (2016) stated that a good budget preparation process is a top down, bottom up approach or a combination of both. In the top down method, top management does its own set of budgeted targets. Meanwhile, budgeting using a bottom up approach is based on the participation of lower level management in the preparation of budget proposals. Whereas the combined approach, based on direction and guidance from senior management, then lower level management defines it into budgets in their respective departments.

\section{Results and Discussion}

Rahardja, Irsad Andriyanto (2014) conducted a study on the role of budget participation on managerial performance in the Work Sutuan for the Regional Government of the City of Semarang. The results of his research show that budget participation has a positive effect on managerial performance. The results of these studies actually support previous similar studies (Winadarta, 2003; Safitri, 2006; Hafiz, 2007).

Furthermore, they argue that the involvement (participation) of management both at the middle and lower levels is very important and relevant because they have the most adequate information about organizational units in their respective environments. Their participation (involvement) will produce a realistic level of difficulty against the budgeted targets so that it is possible to achieve satisfactory results

Budget participation was also carried out by Agus Karyadi, Sunarto (2014) by conducting a study on its effect on managerial performance. The research was conducted with the influence of organizational commitment on managerial performance. The results showed that participation in the preparation had a positive effect on managerial performance. Besides that, organizational commitment also has a positive effect on managerial performance.

Research conducted by Budi Hartono (2016) has proven that participation in the budget preparation process has a positive effect on managerial performance. However, this study has not succeeded in proving the effect of participation in the budgeting process through mediation of organizational commitment. Therefore, further research is still needed by including the Lan variable as a moderating variable.

Guillerma Giusti et al. (2018) conducted a study on the effect of budget participation on managerial performance with organizational commitment and motivation as intervening variables / research was carried out on permanent employees of the Cooperative, Micro, Small and Medium Enterprises Office of Jember Regency. This research shows that budget participation has a positive influence on managerial performance, organizational commitment and motivation. Organizational commitment and motivation have a positive effect on managerial performance. In addition, motivation has a positive effect on organizational commitment.

The influence of budgeting participation on SKPD managerial performance with clarity of budget targets, commitment to budget goals, distributive justice and internal control as intervening variables has been carried 
out by Miftahul Jannah and Sri Rahayu (2015). The study was conducted on 138 middle-level managers at SKPD Jambi Province. The results showed that budgeting participation had no effect on managerial performance. However, budgeting participation had an effect on managerial performance with clarity of budget targets, commitment to budget goals, commitment to budget goals, fair distribution and internal control.

Muhammad Hasby Habibie and Mahmudi (2016) examined the role of individual capacity and work motivation in moderating the relationship between budgeting participation and managerial performance. The study was conducted on the Head of Division, head of subdivisions, supervisors and financial managers at hotel companies in Yogyakarta Solo and Madiun areas. The results of his research indicate that individual capacity and work motivation have a positive effect on managerial performance. This study also shows that there is a two-way interaction between budget participation and individual capacity as well as budget participation and work motivation in strengthening managerial performance.

Muhammad Try Reynaldie, Mahmudi, 2016 examined the influence of leadership style, organizational commitment and environmental uncertainty in moderating the relationship between budgetary participation on performance. The study was conducted on middle-level managers who work for companies in the city of Gresik, East Java. The results showed that leadership style, organizational commitment, and organizational culture had a significant effect in strengthening the relationship between budget participation and managerial performance. Meanwhile, environmental uncertainty has a significant negative effect in influencing the relationship between budgetary participation and managerial performance.

The most recent research that can be disclosed in this study regarding budget participation is research conducted by Kasim Sinen (2020). The research conducted is regarding budgeting participation on managerial performance with procedural fairness and goal commitment as moderating variables. This research is sufficient to prove that participation in budgeting has attracted a lot of research, at least since the research conducted by Argyris (1952) until now.

Most of the variables associated with organizational behavior are related to managerial performance, which is the peak of budgeting targets.

\section{Conclusion}

\subsection{Conclusion}

Based on these discussions, it can be concluded that budget participation is very important in the budget preparation process. Participation in budgeting is the main key to achieving budgeting success. With budgeting participation, management commitment will be achieved to budgeted activities. In the end, budgeting participation will encourage managers' motivation to achieve managerial performance.

This has received great attention from researchers in the field of budgeting. Almost all, at least most researchers are interested in examining budgeting participation on managerial performance and organizational commitment.

\subsection{Suggestions}

Behavioral problems will continue to develop from time to time. Human behavior in the organization will still be the main and determining factor in achieving organizational goals. One of the factors that has been proven by many researchers is that participation in budgeting actually affects various behavioral factors in organizations. Therefore, research on budgeting participation in relation to managerial performance and various behavioral factors in organizations needs to be continued.

\section{Acknowledgments}

This study still contains various limitation. Hopefully, the authors are interested in the same field can develop and improve the quality of study. This study still needs to be developed in terms of its breadth and depth.

\section{References}

1. Agus Karyadi, Sunarto, 2014, Pengaruh Penganggaran Partisipasi, Perencanaan Anggaran, dan Komitmen Organisasi, Terhadap Kinerja Penyususn Anggaran, Telaah Manajemen, 2(1), 93-102. 
2. Budi Hartono Kusuna, 2016, Pengaruh partisipasi Penyusunan Anggaran Terhadap Kinerja Manajerial: Komitmen Organisasi sebagai Variabel Mediasi, Jurnal Akuntansi, Vol.8 No.2, 203 - 213.

3. Brownell, P. and M. Mc Innes, 1986, Budgetary Participation, Motivation, and Managerial Performance, The Accounting Review, 61(4), 587 - 600.

4. Farahmita, Aria, 2013, Pengaruh Kepuasan Kerja dan Pengetahuan tentang Manajemen Biaya Terhadap Hubungan antara Partisipasi Anggaran dengan Kinerja Manajerial, Simposium Nasional Akuntansi XVI.

5. Frucot, Veronique, Shearon, Winston T; 1991, Budgetary participation, locus of Control, and Mexican managerial performance and job satisfaction, The Accounting Review, 66(1), 80-99.

6. Guilerma Giusti, Alwan Sri Kustono, Rochman Effendi, 2018. Pengaruh Partisipasi Anggaran Terhadap Kinerja Manajerial dengan Komitment Organisasi dan Motivasi sebagai variabel Intervening, e-Journal Ekonomi Bisnis dan Akuntansi, 5(2), 121 - 128.

7. Ida Haryanti Mohd Noor Radiah, 2012, Budgetary Participation: How it Affects Performance and Commitment. Accountancy Business and the Public Interest, pp. 53-73.

8. Kasim Sinen, 2020, Partisipasi Penganggaran Terhadap Kinerja Manajerial Dengan Keadilan Prosedural dan Goal Commitment Sebagai Variabel Moderasi, Bongaya Journal for Research in Accounting, 3(2), 122-130.

9. Muhammad Hasby Habibie, Mahmudi, 2016, Peran Kapasitas Individu dan Motivasi Kerja Dalam Memoderasi Hubungan Partisipasi Penyusunan Anggaran Terhadap Kinerja Manajerial, Simposium Nasional Akuntansi XIX.

10. Muhammad Try Reynaldhie, Mahmudi, 2016, Pengaruh Gaya Kepemimpinan, Komitmen Organisasi, Budaya Organisasi dan Ketidakpastian Lingkungan dalam Memoderasi Hubungan Antara Partisipasi Anggaran Terhadap Kinerja Manajerial, Simposium Nasional Akuntansi XIX.

11. Nor, Wahyudin, 2007, Desentralisasi dan Gaya Kepemimpinan sebagai variabel Moderating dalam Hubungan Antara Partisipasi Penyusunan Anggaran dan Kinerja Manajerial, Simposium Nasional Akuntansi X.

12. Poenvati, T; 2002; Pengaruh partisipasi penyususunan anggaran terhadap kinerja manajerial: Budaya Organisasi dan motivasi sebagai variabel moderating, Simposium Nasional Akuntansi V.

13. Rahardja, Irsyad Andriyanto, 2014, Analisis Pengaruh Peran Partisipasi Anggaran terhadap Kinerja Manajerial Dengan Moderasi Locus of Control dan Budaya Organisasi (Studi pada Satuan Kerja Perangkat Daerah Pemerintah Kota Semarang). BISNIS: Jurnal Bisnis dan Manajemen Islam, 2(1), 4160.

14. Winadarta, Nitya, 2003, Analisis Pengaruh Partisipasi Penyusunan Anggaran Terhadap Kinerja Manajerial dengan Kultur Organisasi dan Lucus of Control sebagai Moderating. Master thesis, Universitas Diponegoro, Semarang. 